\title{
Preliminary results of a farmstead survey of the Great Hungarian Plain
}

Mátyás Szabó

Corvinus University of Budapest

Institute of Geography, Geoeconomy and Sustainable

Development,

Hungary

E-mail:

matyas.szabo@uni-corvinus.hu

Orsolya Pap-Szuromi

GreenDependent Institute,

Hungary

E-mail: szuromi.orsi@gmail.com

Róbert Romvári

Szent István University

Enyedi György Doctoral School of

Regional Sciences,

Hungary

E-mail: romvarirobi@gmail.com

Keywords:

rural development, scattered farmsteads, infrastructural features, Great Hungarian Plain, Farmstead Development

Programme
A common problem with research into farmsteads is that, at present, there is no universally-accepted definition of a farmstead. Another problem specific to the Hungarian context is that no exact data are available for the number of farmsteads on the Great Hungarian Plain in recent decades. Recognizing this problem, a farmstead survey targeting the delineation of the Farmstead Development Programme was carried out in 2016. The authors of the study attempted to collect the data and databases currently available about farmsteads and peripheral residential areas and present a background to the survey carried out in 2016. The results of the survey allow to identify new trends, such as farmsteads becoming territorially more fragmented and the transformation of farms away from their traditional functions.

Regional Statistics, Vol. 8. No. 2. 2018: 92-108; DOI: 10.15196/RS080208 


\section{Introduction}

The quality and historical continuity of the data available on farmsteads, as well as the comparability of the data measured during each period, primarily depend on the criteria that different surveys and databases use to define a farmstead.

Data on farmsteads, including on the people living in farmsteads, are available in the time series taken mainly from the population censuses of the Hungarian Central Statistical Office (HCSO). The problem with these data is that, since the population census of 1990, the HCSO has not separated out data collected on the number of people living in farmsteads, instead of publishing data showing the number of people living in peripheral residential areas ${ }^{1}$ (Font 2006). A peripheral residential area includes parts of inhabited local administrative units located on the outskirts of municipalities - such as a watch-house, a forester's lodge, a village-like settlement with a street, a garden plot, a single farmstead or a group of farmsteads, or a factory housing estate - meaning that the HCSO data are representative of several types of residential areas combined, and not just farmsteads (HCSO 2018). Thus, at present, no single database provides data on the current state of Hungarian farmsteads or their demographic, economic, and environmental characteristics.

In connection with the definition of the farmstead, it is also important to note that legislative and other development policy documents and databases sometimes use different definitions and stress different aspects of the farmstead lifestyle.

For example, in 2009, the Hungarian Parliament passed the 49/2009 (V. 27.) resolution, referred to by Becsei (2016) as the farmstead law, which aims to preserve and develop farmsteads and farming areas. This piece of legislation refers to a farmstead as a traditional type of agriculture, settlement, and lifestyle that is part of the Hungarian social, settlement pattern, and economic bistory heritage going back hundreds of years. Due to its unique socio-geographical, architectural, linguistic, ethnographic, and landscape features, the farmstead settlement system forms part of the Hungarian national heritage and, thus, of the European heritage.

The above resolution was the basis for the delineation adopted by the Farmstead Development Programme ('the Programme'), announced every year since 2011. Furthermore, the Programme used the farmstead definition outlined in Section 5(25) of Act CXXII of 2013 on agricultural and forestry land trade for determining the entitlement of farmers applying for grants. Pursuant to this law, a farmstead refers to: a plot of land not larger than one hectare located on the outskirts of a settlement to which - apart from the land - belongs a residential and farmstead building or group of such buildings erected for the purpose of plant and livestock production and product processing and storage related thereto, or a plot of land registered in the land registry as a farmstead. The Pro-

\footnotetext{
${ }^{1}$ Inhabitant of the outskirts is a broader category than number of people living in farmsteads. An inhabited area of outskirts is - according to the practice of population census - an inhabited area where at least one person was enumerated or lives and at least one unoccupied but usable dwelling can be found (HCSO 2019).
}

Regional Statistics, Vol. 8. No. 2. 2018: 92-108; DOI: 10.15196/RS080208 
gramme considers the whole of the Great Hungarian Plain as the recipient region (an area spanning six Great Hungarian Plain counties and nine southern districts of Pest county and currently consisting of 724 settlements).

However, according to the National Spatial Development Concept (NSDC) of 2005, farming areas are not restricted solely to the Great Hungarian Plain, as they can also include settlements where the population on the outskirts is at least 200, with a minimum of $2 \%$ of the population belonging to farming areas. Based on this definition, 280 settlements are considered parts of farming areas.

Contrary to the NSDC, the farmstead definition used by the National Development and Territorial Development Concept is better suited for potential applicants to the Farmstead Development Programme: Scarcely inhabited outskirts of settlements typical for the areas of the Great Hungarian Plain with a dwelling function, a traditionally important agricultural role, and an increased touristic and recreational function.

However, it is worth noting that the Rural Development Programme (RDP), corresponding to the seven-year-long programming period between 2014-2020, uses the aforementioned definition of Act CXXII of 2013 for identifying farmsteads (Rural Development Programme 2014-2020) and, thus, it is not surprising that the delineation of the RDP grant announcements for developing farming areas corresponds to those indicated in the Programme.

The delineation of farming areas can also provide an anchor for specific land coverage databases. The CORINE database CLC50 (1:50,000 scale) initiated by the European Union (EU) and, in Hungary, managed by the Government Office of the Capital City Budapest, Department of Geodesy, Remote Sensing and Land Offices (DGRSLO), uses the following delineation for farming areas: typically, especially for the Great Hungarian Plain, a complex agricultural environment with scattered buildings. In the CLC50 database, the smallest charted unit is four hectares; thus, farmsteads situated close to each other (not further than 200 meters), none smaller than four hectares (buildings with vegetable gardens and trees), are measured together, but farmsteads situated more than 200 meters from each other and smaller than four hectares are not shown (Szabó 2010). In contrast, under the definition outlined in the Land Trade Act, a plot of land situated on the outskirts of a settlement and smaller than one hectare can be considered a farmstead, which shows that the number of farmsteads and the location of farming areas vary in each database.

\section{Previous survey and background}

According to Székely and Kotosz (2018), although farmsteads have been examined by researchers for a long time, these analyses are not systematic, but rather specific. The authors of this study agree with this assessment, as following political change, only minor territorial units (not larger than a county) has been involved into farmstead researches.

Regional Statistics, Vol. 8. No. 2. 2018: 92-108; DOI: 10.15196/RS080208 
From these works, we would like to highlight the research carried out in 20022003 by the professors and students of Szent István University, Corvinus University of Budapest, Eszterházy Károly University (formerly Károly Róbert College), and John Von Neumann University (formerly Kecskeméti College) under the control of the Centre of Regional Studies of Hungarian Academy of Sciences, Great Plain Research Institute; this study involved 825 farmsteads in 24 settlements in the area of Kiskunság. The primary objective of the research was 'to shed light on the farmsteads and the people living in these farmsteads, the reasons, circumstance and consequences of the positive and negative changes' (Csatári-Kiss 2004).

The fieldwork carried out by the Centre of Regional Studies of Hungarian Academy of Sciences, Great Plain Research Institute in 2005 across 104 settlements in Homokhátság is also noteworthy. In this survey, the researchers examined and analyzed farmsteads based on five thematic units (society, built environment, type of farmstead, and certain progressive elements). In the course of the study, 39,251 farmsteads were surveyed (Czene-Jávor 2006).

It is important to ascertain the objectives of the Farmstead Development Programme, initiated in 2011 and financed entirely by the Hungarian government, which supports area and county surveys of farmsteads. Under the objectives above, five organizations in 2011, four in 2012, and three in 2013 received financial aid. Among the projects that received aid, a farmstead survey covering 200 settlements (nearly 34,000 farms) was carried out with the use of a uniform and centrallyapproved questionnaire.

Here, we would like to stress one of the conclusions on the farmsteads of the Kiskunfélegyháza area from the 2012 survey: 'Unfortunately, there are several farmstead numbers in the databases, under which the farmstead has already disappeared. This is also due to the failure of the owner to report that the farmstead has ceased to operate, they plough the area' (Farmstead Development Programme of the Kiskunmajsa area 2012).

We should also point out that research was conducted in the neighboring countries and financed by the Hungarian Ministry of Agriculture. In 2016, there were surveys in the scattered farmsteads of Partium (RO) and Székelyföld (RO), where thousands of responses were recorded (Geréb 2017, Szilágyi 2017).

Based on the objectives of the Hungarian government, according to which, by 2020 every farmstead in Hungary should have electricity and should be accessible by road, a comprehensive survey of farmsteads was undertaken in 2016. The survey, reflecting the delineation of the Farmstead Development Programme, that is, covering 724 settlements on the Great Hungarian Plain, was induced by the fact that Hungary has no accurate and up-to-date information about the geographical location of farmsteads, the population living in farmsteads, or the demographic and economic situation of the farmstead population (Dobai et al. 2018).

Regional Statistics, Vol. 8. No. 2. 2018: $92-108$; DOI: 10.15196/RS080208 


\section{6 survey objectives and methodology}

The primary objective of the 2016 survey was to compile a database in which geographical coordinates can be used to identify the farmsteads on the Great Hungarian Plain. Another important objective was the preparation of a study presenting the situation of those farmsteads that are still without electricity and highlighting possibilities and proposals in connection with lack of access to electricity.

Based on the decision made during the cabinet meeting on $18^{\text {th }}$ August 2015, the field work for the survey was carried out between March and April 2016 by the Government Offices. The work of the Government Offices was partly assisted by farmstead caretakers (a type of public service), family support workers, and field watchmen with appropriate local knowledge. The Ministry of Agriculture drafted the questionnaire used during the fieldwork and the related explanatory notes. The materials were drafted based on previous survey documents and the practical experiences of several farmstead researchers. The questions included in the questionnaire can be classified into eight thematic groups:

1. Locations of farmsteads

2. State of natural environment around farmsteads

3. Population

4. State of farmstead buildings

5. Infrastructure situation

6. Wired electricity supply

7. Farming

8. Farmstead Development Programme and other grants

The Ministry of Agriculture consulted several other ministries before compiling the questionnaire used during the fieldwork to more precisely define the range of farmsteads to be included in the survey. As a result of these consultations, a background table was compiled with the help of the DGRSLO, which included the land registry database (LRD), vector topographic map database (VTMD), and the data of the Land Parcel Identification System (LPIS) related to farmsteads. DGRSLO used the following queries during data sorting:

- an analysis focusing only on outlying plots and garden-plots;

- plots that were shown to be a farmstead, school, farmhouse, and so on were sorted from the land registry database;

- plots overlapping with the one-meter zone of farmstead objects sorted from the 10v.1 database of DITAB (Digital Topographic Database) were sorted from the topographic database of the land registry;

- plots overlapping with the one-meter zone of farmstead objects of the Cover Database of the LPIS were sorted from the topographic database of the land registry.

Table 1 includes the county-level summaries of the mentioned data sources.

Regional Statistics, Vol. 8. No. 2. 2018: 92-108; DOI: 10.15196/RS080208 
Table 1

Farmstead-related county-level summaries of the databases

\begin{tabular}{l|c|c|c|c|c|c}
\hline \multicolumn{1}{c|}{ County } & $\begin{array}{c}\text { Settlement } \\
\text { with farm- } \\
\text { steads based } \\
\text { on LRD } \\
\text { (number) }\end{array}$ & $\begin{array}{c}\text { Farmsteads } \\
\text { based on } \\
\text { LRD } \\
\text { (number) }\end{array}$ & $\begin{array}{c}\text { Settlements } \\
\text { with farm- } \\
\text { steads based } \\
\text { on the } \\
\text { VTMD } \\
\text { (number) }\end{array}$ & $\begin{array}{c}\text { Farmsteads } \\
\text { based on the } \\
\text { VTMD } \\
\text { (number) }\end{array}$ & $\begin{array}{c}\text { Settlements } \\
\text { with farm- } \\
\text { steads based } \\
\text { on the LPIS } \\
\text { (number) }\end{array}$ & $\begin{array}{c}\text { Farmsteads } \\
\text { based on the } \\
\text { LPIS } \\
\text { (number) }\end{array}$ \\
\hline Bács-Kiskun & 119 & 18,809 & 116 & 68,160 & 108 & 22,479 \\
Békés & 75 & 6,568 & 73 & 20,944 & 71 & 12,136 \\
Csongrád & 66 & 9,050 & 65 & 45,429 & 61 & 27,319 \\
Hajdú-Bihar & 85 & 18,733 & 72 & 9,718 & 70 & 4,852 \\
Jász-Nagykun-Szolnok & 77 & 6,551 & 72 & 9,826 & 65 & 4,181 \\
Pest & 80 & 11,021 & 74 & 15,310 & 60 & 5,289 \\
Szabolcs-Szatmár-Bereg & 218 & 20,126 & 186 & 5,935 & 108 & 1,847 \\
Total & $\mathbf{7 2 0}$ & $\mathbf{9 0 , 8 5 8}$ & $\mathbf{6 5 8}$ & $\mathbf{1 7 5 , 3 2 2}$ & $\mathbf{5 4 3}$ & $\mathbf{7 8 , 1 0 3}$
\end{tabular}

Source: Own elaboration based on DGRSLO data.

Table 1 demonstrates that the databases registering farmsteads are not uniform. The number of settlements with farmsteads belonging to the counties of the Great Hungarian Plain (see Table 2) and the total number of farmsteads varies significantly.

It must be emphasized that the data presented in Tables 1 and 2 (for the year 2015) come from public databases. The data are handled and recorded by the Government Office of the Capital City Budapest.

Table 2

Settlements with the highest number of farmsteads based on different databases

\begin{tabular}{c|l|c|l|c|l|c}
\hline $\begin{array}{c}\text { Serial } \\
\text { number }\end{array}$ & \multicolumn{1}{|c|}{ LRD } & $\begin{array}{c}\text { Farmsteads } \\
\text { (number) }\end{array}$ & \multicolumn{1}{|c|}{ VTMD } & $\begin{array}{c}\text { Farmsteads } \\
\text { (number) }\end{array}$ & \multicolumn{1}{|c|}{ LPIS } & $\begin{array}{c}\text { Farmsteads } \\
\text { (number) }\end{array}$ \\
\hline 1. & Kecskemét & 3,882 & Kecskemét & 6,680 & Kiskunfélegyháza & 2,284 \\
2. & Nyíregyháza & 2,786 & Kiskunfélegyháza & 4,287 & Hódmezővásárhely & 1,974 \\
3. & Kiskunfélegyháza & 2,023 & Kiskunmajsa & 3,586 & Békéscsaba & 1,949 \\
4. & Lajosmizse & 1,568 & Debrecen & 3,574 & Debrecen & 1,913 \\
5. & Kiskunmajsa & 1,564 & Kiskunhalas & 3,517 & Balástya & 1,885
\end{tabular}

Source: Own elaboration based on DGRSLO data.

Besides the numerical data presented above, the $40 \mathrm{~cm} / \mathrm{px}$ georeferenced orthophotographs prepared in 2015 regarding the research observation area were received from Government Office of the Capital City Budapest, the Department of Geodesy Remote Sensing, and Land Offices. These orthophotographs have been developed. The orthophotographs are used for the validation of the GPS coordinates registered during the survey and to check the state of the farmsteads.

Regional Statistics, Vol. 8. No. 2. 2018: $92-108$; DOI: 10.15196/RS080208 


\section{Preliminary results of the 2016 survey on the farmsteads of the Great Hungarian Plain}

During the fieldwork, the interviewers recorded 94,644 data sheets. Following the recording, the Herman Otto Institute built an SQL-based database with the assistance of the Ministry of Agriculture and carried out a preliminary feasibility study, in which the authors presented the situation of farmsteads without electricity and formulated possibilities and proposals for how to solve the problem of electricity supply.

Guided by the original purpose of the survey, we subsequently sorted those farmsteads with residential and economic functions but no electricity - that is, no connection to the power grid or no isolated power system - from the total sample. This search shows that 4,779 farmsteads have no electricity, and it can also be said that no data related to this question are available in the case of nearly $41 \%$ of the surveyed farmsteads.

It should also be mentioned here that, in the course of preparing the present study, we had access to the background materials jointly prepared by the Ministry of Agriculture and the Herman Otto Institute, which already analyzed some questions from the 2016 survey on the Great Hungarian Plain concerning access to electricity. In the material above, the authors stated under the question concerning distance from the nearest power grid connection that the owners of the farmsteads could answer the question with relative accuracy. To record the accurate distances, the authors of the background material contacted the Lechner Nonprofit Ltd., the operator of the E-utility system (unified electronic register of public utilities). Table 3 contains the information obtained from the respondents, supplemented with the data received from the operator.

Table 3

The distances between farmsteads and the nearest power grid connection

\begin{tabular}{l|c|c|c|c|c}
\hline \multirow{2}{*}{ No. } & \multirow{2}{*}{$\begin{array}{c}\text { Distance from } \\
\text { the grid }(\mathrm{m})\end{array}$} & \multicolumn{2}{|c|}{ Based on the questionnaire } & \multicolumn{2}{c}{$\begin{array}{c}\text { Based on the data collected } \\
\text { by Lechner Nonprofit Ltd. }\end{array}$} \\
\cline { 3 - 6 } & $\begin{array}{c}\text { Number of } \\
\text { responses }\end{array}$ & $\begin{array}{c}\text { Percentage of } \\
\text { responses }\end{array}$ & $\begin{array}{c}\text { Number of } \\
\text { responses }\end{array}$ & $\begin{array}{c}\text { Percentage of } \\
\text { responses }\end{array}$ \\
\hline 1. & $<50$ & 1,032 & 35.2 & 968 & 21.0 \\
2. & $50-1000$ & 390 & 13.3 & 3,110 & 67.4 \\
3. & $1000-2000$ & 111 & 3.8 & 436 & 9.4 \\
4. $2000<$ & 1,398 & $\mathbf{4 7 . 7}$ & 102 & 2.2 \\
\multicolumn{2}{l|}{ Total } & $\mathbf{2 , 9 3 1}$ & $\mathbf{1 0 0}$ & $\mathbf{4 , 6 1 6}$ & $\mathbf{1 0 0}$
\end{tabular}

Source: Own elaboration based on information from the Ministry of Agriculture, Herman Otto Institute, and Lechner Nonprofit Ltd.

Table 3 shows that, according to the questionnaire, $61.5 \%$ of the owners of the farmsteads without electricity $(4,779)$ responded to the question concerning the

Regional Statistics, Vol. 8. No. 2. 2018: 92-108; DOI: 10.15196/RS080208 
distance from the power grid. In contrast, the data of the Lechner Knowledge Centre relate to $96.2 \%$ of the total sample.

Cleansing and organizing the inventoried data are part of the process of building the involved database. As a result of this process, it is considered that the GPS coordinates of nearly 3,000 farmsteads from the full sample could not be analyzed, as either the latitudinal or longitudinal coordinates were missing. There were cases in which, according to the coordinates, the farmstead was not situated within the boundaries of the analyzed area (in extreme cases, it was located outside Hungary). At the end of the data cleansing and organization, data were available for 91,806 farmsteads. With the use of these data and the ArcGIS 10.4.1 software, we drew up a density map dividing the territory of Hungary into a grid of squares of $1 \mathrm{x} 1 \mathrm{~km}$ (see Figure 1).

Figure 1

\section{Geographic representation of the surveyed farmsteads}

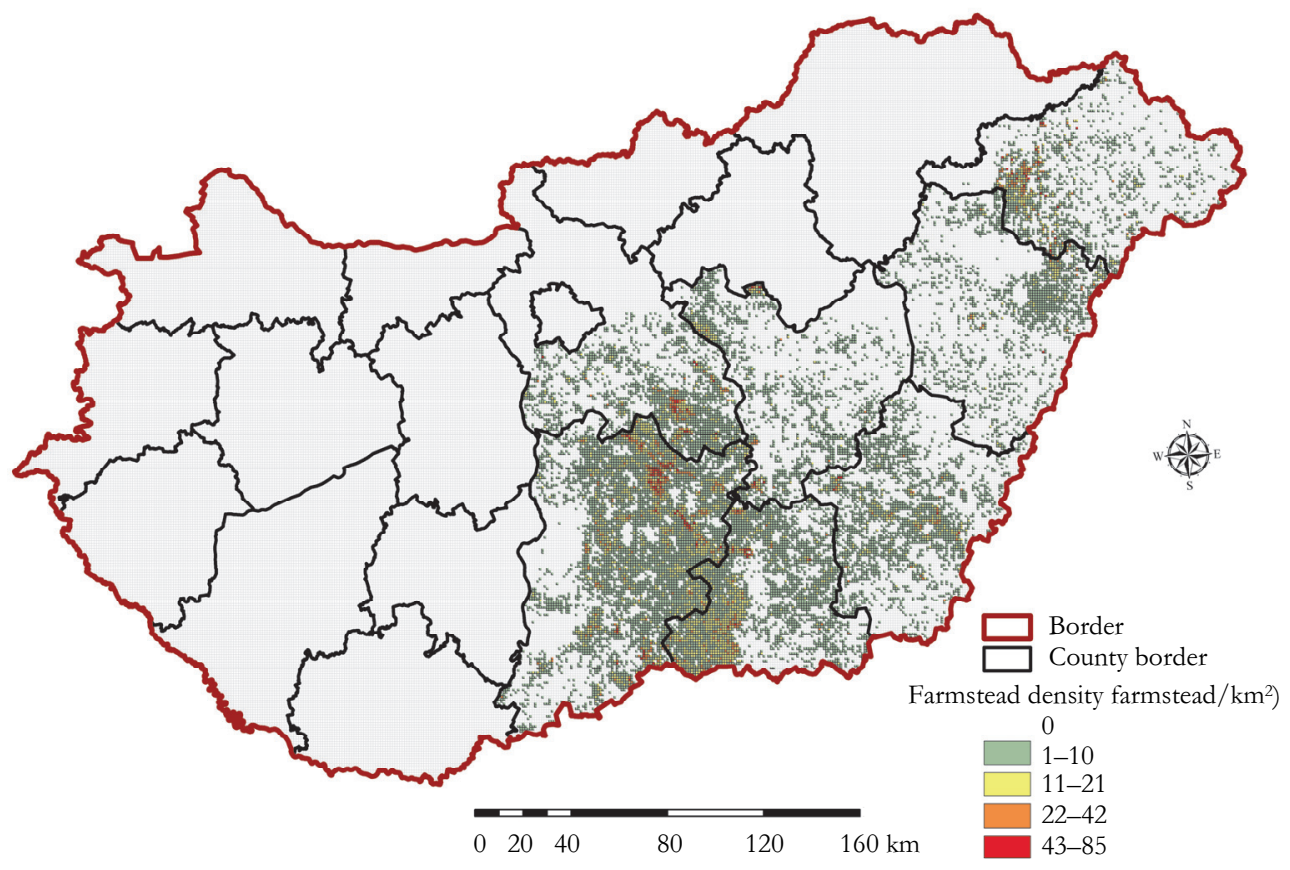

Source: Edited by Róbert Romvári.

Figure 1 shows that the areas of the Great Hungarian Plain with the highest number of farmsteads are the environs of Homokhátság, Nyíregyháza, and Békéscsaba. These three hubs correspond to the three typical types of areas with farmsteads: the dispersed settlements around Kecskemét, the so-called 'sortanya' (a number of farmsteads along dirt roads) typical of Békés county, and the so-called

Regional Statistics, Vol. 8. No. 2. 2018: $92-108$; DOI: 10.15196/RS080208 
'bokortanya' (farmsteads scattered across arable land) in the area of Nyíregyháza (Romvári 2017).

In recent years a remarkable increase of territorial population disparities can be seen within the Great Plain (Obádovics 2013). According to the projections prepared by Hablicsek (2007), the Southern and the Northern Great Plain population will decrease by 340,960 between 1980 and 2021. In terms of population loss, the Great Plain as a whole was ranked second behind Northern Hungary. However, comparing the real and the projected population an underestimation of an approximate 1-1.5 percentage can be detected in 2011 within the Great Plain region.

Using the principal component analysis Kulcsár et al. (2011) classified microregions by age structure and regional development. According to the result, the Southern Great Plain can be characterized by aging micro-regions and average development indicators. In contrast, young age structure and economic underdevelopment are characteristic within a remarkable part of the Northern Great Plain.

Using vector maps and a GIS program, we examined the number of farmsteads - from the 91,806 (see Figure 1) - located in the inner belt area or other central parts of the 724 settlements. As a result of this sorting, we found that 1,674 farms are located in such zone.

Subsequently, we carried out a preliminary analysis of each question concerning the total sample $(94,644)$. It should be noted before the presentation of the results that the poor quality of survey data did not allow to conduct a deeper examination. In general, the responses to the questions included in each of the thematic groups show substantial lack of data. A recurring problem throughout the processing of the data sheets was that the respondent did not use the unit of measurement defined in advance, meaning that the results were largely distorted and not representative of reality. Based on these, we analyzed only those answers where the responses were relatable to the whole sample. However, when smaller geographic units are examined (case studies), other variables that are not handled by this study may be subject to substantive analysis. Such indicators may include: the distance of surveyed farmsteads from the settlement; the distance from the nearest solid paved road; the type of agricultural activity; whether farmsteads engage in tourism, organic farming, or food processing; and the use of renewable energy sources.

For cases in which we analyzed the number of farmsteads belonging to a settlement, it can be established that the highest number of dispersed settlements were registered in Kecskemét $(4,765)$, Nyíregyháza $(2,965)$, Kiskunfélegyháza $(2,259)$, Lajosmizse $(1,697)$, and Cegléd $(1,450)$. However, we found that, contrary to the size of the surveyed area (724 settlements), in the framework of the Great Hungarian Plain survey of 2016, farmsteads were registered in the outskirts of 'only' 675 settlements.

As we have already mentioned in the methodological part of the paper, the survey included questions concerning the relations between the farmsteads and the natural environment. In what follows, we would like to present some of these ques-

Regional Statistics, Vol. 8. No. 2. 2018: 92-108; DOI: 10.15196/RS080208 
tions. The presentation of the protected natural features of the farmstead areas of the Great Hungarian Plain shows that some national parks and areas protected at the national level and Natura 2000 areas enrich the lowland landscape, making it valuable and interesting. Based on the data published by the Ministry of Agriculture in December 2017, there are 10 national parks, 171 conservation areas, 39 landscape parks, and 88 nature value sites in Hungary (Ministry of Agriculture 2018). Each of the categories above can also be found within the boundaries of the research sample area. The survey analyzed whether each farmstead is part of the Natura 2000 area. Based on the responses, only $1.1 \%$ of the total sample is situated in Natura 2000 areas; however, according to the vector topographic map data available to us, three times more farmsteads can be found in the Natura 2000 areas. Based on the responses given to the question on whether the farmstead is part of any of area marked for conservation, 597 farmsteads are situated in national parks, 459 farmsteads in conservation areas, and 393 farmsteads in landscape parks, and we do not have adequate data regarding 13,502 farmsteads. According to the topographic data, the correct number for the above information are 941, 85, and 368, respectively. Based on the responses, it appears that many of the owners do not know the conservation status of his or her farmstead.

Regarding the environmental status of the surveyed farmsteads, based on nearly 80,000 responses, we can state that a significant portion of the farmsteads in the Great Hungarian Plain, i.e. $80.5 \%$, has preserved its traditional architectural nature up to the present date. A further $10.3 \%$ of the farmsteads have a combination of modern and old-style buildings, and $9.2 \%$ have new and modern buildings.

A subsequently processed question concerns the year of construction of the residential building of the surveyed farmstead. The questionnaire defined ex-ante four possible responses: the residential building was constructed before 1945, between 1945 and 1989, between 1990 and 2000, or after 2000. Figure 2 shows the county distribution of the farmsteads for which we had adequate data $(48,491)$.

Figure 2 shows that the vast majority of the surveyed farmsteads $(90 \%)$ were built before the regime change of 1989. It is interesting to note that the number of farmsteads built between 1945 and $1989(21,764)$ is almost the same as the number of buildings constructed before the end of the Second World War $(21,936)$. These data are especially interesting since, in the 1950s, a moratorium on buildings was introduced in peripheral areas, which was only lifted in 1986 (Csatári-Kiss 2004). According to Duró (1990), this regulation deprived the population of the peripheral areas of even the possibility of constructing buildings from their resources. According to Dövényi (2003), the peripheral population of the Great Hungarian Plain fell by one-fifth between 1949 and 1960. However, the demographic decline of the peripheral areas showed significant territorial differences (Beluszky 1983). The greatest 'losers' during this period were farmsteads in Tiszántúl, while the farmsteads of Homokhátság were least affected.

Regional Statistics, Vol. 8. No. 2. 2018: 92-108; DOI: 10.15196/RS080208 
Figure 2

\section{Distribution of surveyed farmsteads by year of construction of their residential buildings}

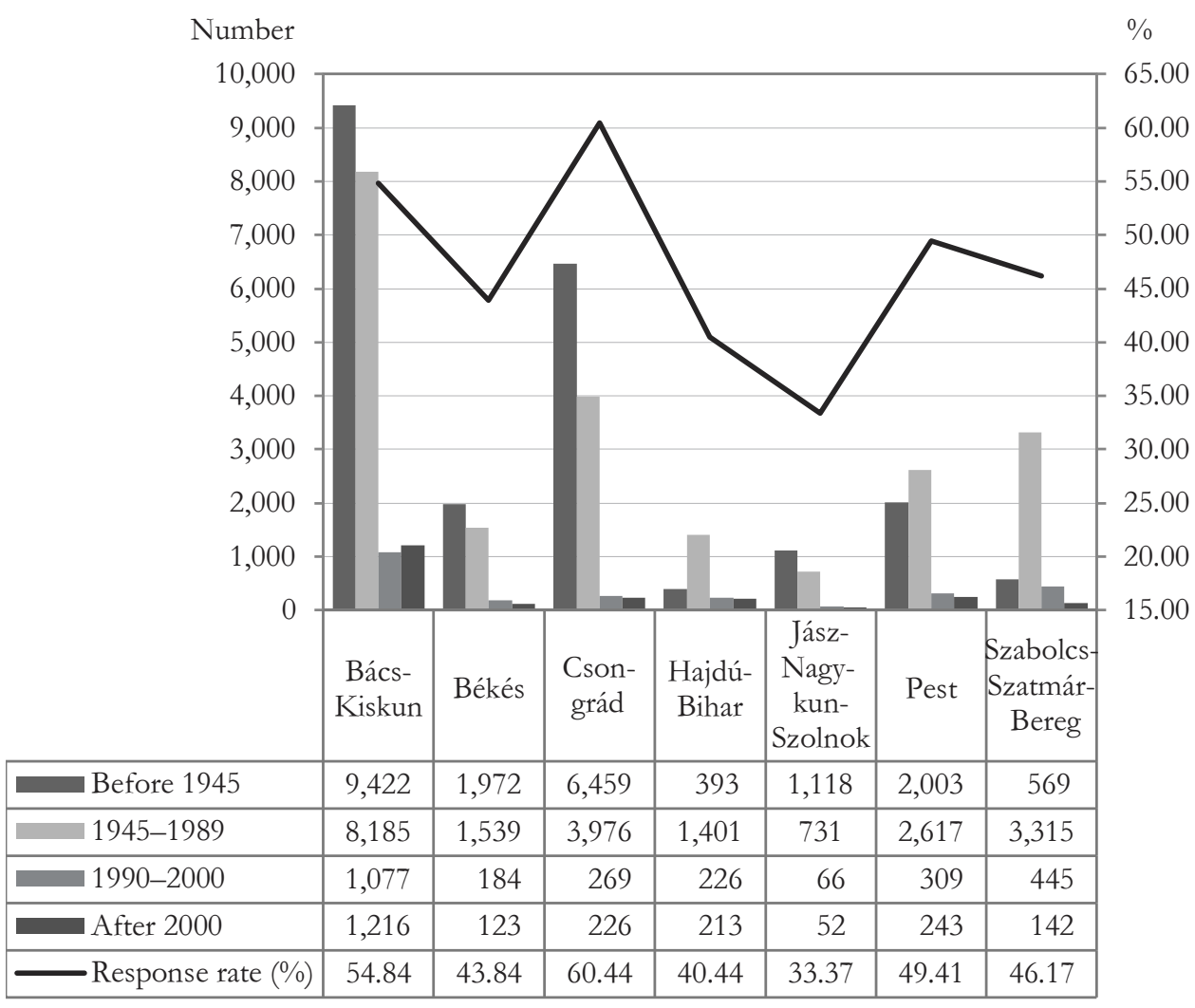

Source: Own elaboration based on the survey.

The traditional functions of farmsteads have undergone significant changes during recent decades. The literature indicates that traditional farming has been in retreat and that the role of farmsteads has become more diverse, with an increasing number of farmsteads becoming active in catering and tourism, and the number of hobby farmsteads has been increasing over recent decades (Csatári-Kiss 2004, Kozma 2011, Székely-Kotosz 2018). When looking at the distribution of farmsteads according to their dwelling function, based on 49,488 responses, $79 \%$ of the farmsteads are permanently inhabited. The proportion of uninhabited farmsteads is around $12 \%$. However, a considerable portion of these dispersed settlements has some economic function. A total of $8.5 \%$ of the analyzed farmsteads function as hobby farmsteads.

Regional Statistics, Vol. 8. No. 2. 2018: 92-108; DOI: 10.15196/RS080208 
Regarding the farming function the majority (58\%) of the surveyed farmsteads (based on 24,000 responses), produce for their own consumption, that is, their products are not sold. A total of $23 \%$ of the farms sell any surplus not meant for own consumption (not more than $50 \%$ of the produced goods), while $19 \%$ of the respondents produce mainly for the purpose of selling (at least $51 \%$ of the produced goods are sold).

In the case of farmsteads used for farming, based on 38,425 responses, in more than $80 \%$ of the farmsteads, the size of the plot directly belonging to the farmstead is one hectare or less. These farms, based on their size, meet the following part of the definition of a farmstead used in the Farmstead Development Programme: ' $a$ plot of land not larger than 1 hectare located in the outskirts of a settlement to which - apart from the land - belongs a residential and farm building or group of such buildings erected for plant and livestock production and product processing and storage related thereto'. Farms with a plot larger than one hectare $(8,000)$ are considered farmsteads according to the following part of the definition: 'a plot of land registered in the land registry as farmstead'.

The 2016 survey analyzed the proportion of the agricultural areas around the farmsteads. Based on nearly 61,000 responses, in the case of half of the farmsteads, this proportion is more than $80 \%$, while in the case of $27 \%$ of the farmsteads, less than one-fifth of the area of the farmstead is used for arable farming.

This survey did not investigate whether the farmstead infrastructure involved an appropriate road network or not. Among others, the transport situation can be characterized by the so-called accessibility index which is based on time, not distance. Within the Great Plain, the average micro-level accessibility time (10.0-29.9 minutes) of the central town from a given settlement is around the country average. However, Békés county has the slowest nationwide approach (up to 90 minutes) from the express road junctions (Novák-Varsányi 2011).

In the framework of the survey, the experts analyzed the infrastructural situation of the given farmstead. They asked about the electricity, gas, and drinking water supply of the property. In the course of processing the data, we produced an index value from the responses given to the questions mentioned above. We included only those farmsteads in the comparison, whose owners provided valid responses to all the questions, a total of 43,016 farmsteads. We followed the below logic when producing the index value:

Electricity supply:

- the farmstead has electricity and is connected to the power grid -2 points

- the farmstead uses an isolated power system - 1 point

- the farmstead has no electricity -0 point

Gas supply:

- the farmstead has a gas connection -2 points

- the farmstead uses liquid petroleum gas -1 point

- the farmstead has no gas connection -0 point

Regional Statistics, Vol. 8. No. 2. 2018: $92-108$; DOI: 10.15196/RS080208 
Drinking water supply:

- the farmstead is connected to the drinking water distribution network -2 points

- the farmstead solves the question of drinking water with a driven well -1 point

- the farmstead has water quality problems -0 point

After we arranged the farmsteads in order, according to the mentioned logic, we defined three categories: 1. Farmsteads with an unfavorable infrastructural situation (0-1 point); 2. Farmsteads with an average infrastructural situation (2-4 points); 3. Farmsteads with a favorable infrastructural situation (5-6 points). We derived the results shown in Table 4, broken down by county.

Table 4

Infrastructure features of the surveyed farmsteads

\begin{tabular}{l|r|r|r|r|r|r|r}
\hline \multirow{2}{*}{ County } & \multirow{2}{*}{$\begin{array}{c}\text { Number } \\
\text { of sur- } \\
\text { veyed }\end{array}$} & \multicolumn{2}{|c|}{ Unfavorable state } & \multicolumn{2}{|c|}{ Average state } & \multicolumn{2}{c}{ Favorable state } \\
\cline { 5 - 8 } & farmsteads & Number & $\%$ & Number & $\%$ & Number & $\%$ \\
\hline Bács-Kiskun & 17,943 & 432 & 2.41 & 12,977 & 72.32 & 4,534 & 25.27 \\
Békés & 3,497 & 37 & 1.06 & 2,172 & 62.11 & 1,288 & 36.83 \\
Csongrád & 8,443 & 1,349 & 15.98 & 5,215 & 61.77 & 1,879 & 22.26 \\
Hajdú-Bihar & 2,323 & 61 & 2.63 & 1,626 & 70.00 & 636 & 27.38 \\
Jász-Nagykun-Szolnok & 1,526 & 59 & 3.87 & 1,066 & 69.86 & 401 & 26.28 \\
Pest & 4,900 & 65 & 1.33 & 3,751 & 76.55 & 1,084 & 22.12 \\
Szabolcs-Szatmár-Bereg & 4,384 & 23 & 0.52 & 1,269 & 28.95 & 3,092 & 70.53 \\
Total & $\mathbf{4 3 , 0 1 6}$ & $\mathbf{2 , 0 2 6}$ & $\mathbf{4 . 7 1}$ & $\mathbf{2 8 , 0 7 6}$ & $\mathbf{6 5 . 2 7}$ & $\mathbf{1 2 , 9 1 4}$ & $\mathbf{3 0 . 0 2}$
\end{tabular}

Source: Own elaboration based on the survey.

Table 4 shows that $4.7 \%$ of the farmsteads are in unfavorable state, $65.3 \%$ in average state and $30 \%$ in favorable infrastructural state. However, there are significant differences in the distribution of each category by county (written in Table 4 in bold type):

- While the proportion of properties in unfavorable situations varied, on average, between $0.5 \%$ and $4 \%$, in Csongrád county this value was $16 \%$;

- The average value of the average farmstead by county varied between $61 \%$ and 76\%; however, in Szabolcs-Szatmár-Bereg county this value was 29\%;

- The average value of the favorable situation category varied between $22 \%$ and $37 \%$. From this value, the farmsteads of Szabolcs-Szatmár-Bereg county showed a different result, measuring $70.5 \%$.

Overall, $93 \%$ of the surveyed respondents had wired electricity, $22 \%$ piped gas and $26 \%$ piped drinking water. A total of $22 \%$ of the analyzed farmsteads had a gas connection, while $26 \%$ of them had a connection to the drinking water distribution system.

Regional Statistics, Vol. 8. No. 2. 2018: 92 -108; DOI: 10.15196/RS080208 
Analysis of the phone connections of the farmsteads, based on 41,048 responses, showed that $5 \%$ of the farmsteads have a fixed telephone and $69 \%$ of the population has a mobile phone connection. A total of $17 \%$ of the population has a fixed or mobile phone connection. Analyzing access to the internet, the results show significant differences compared to the national average. Based on HCSO 2016 data, nearly $80 \%$ of the households in Hungary had access to the internet; in the case of the farmsteads, based on 36,666 responses, this rate is $38 \%$. According to the HCSO data, the internet penetration rate of the total population in the Northern Great Plain and the Southern Great Plain was lower than the national average (in 2016 this value was $72 \%$ in the regions of the Great Plain) (HCSO 2017b).

In the survey under review, the data show that the highest internet penetration is in the counties of Pest and Békés (47.8\% and $44.0 \%$, respectively), and the lowest rate of penetration can be found in Csongrád county (29.8\%). Based on the data, the farmsteads of Csongrád were the least developed. However, the internet penetration rate of the total population of Csongrád county was above the national average (this difference could be affected by the lower response rate of Csongrád, which was under $40 \%)$.

\section{Conclusions}

Over the last two decades, farmsteads have become territorially more fragmented. No accurate information existed about the geographic location and general state of Hungarian farmsteads. Acknowledging this gap, a survey of the farmsteads of the Great Hungarian Plain was carried out in 2016. By using the GPS coordinates recorded during the fieldwork, a map of the whole territory of the Great Hungarian Plain showing the farmsteads was drawn up.

The number of farmsteads and their population has diminished over recent decades. Alongside others, this survey gave us a fresh territorial picture of the 'living' farmsteads, so we can now prove that the areas of the Great Hungarian Plain with the highest number of active farmsteads are the environs of Homokhátság, Nyíregyháza, and Békéscsaba, with three typical types of settlements: scattered farmsteads, the 'sortanya', and the 'bokortanya'.

In parallel with these processes, the traditional functions have also transformed: a total of $79 \%$ of the farmsteads are permanently inhabited; uninhabited farmsteads make up around $12 \%$ of the total; however, a considerable part of these dispersed settlements has some kind of economic function. Hobby farmsteads, purchased only for recreational purposes, have appeared, and in the context of being multifaceted and diverse, more and more farmsteads have become active in catering, tourism, and artisanal activity. In the field of environment, a large number of the owners do not know the exact conservation status of his or her farmstead, and a significant portion of the farmsteads, i.e. $80.5 \%$, has preserved its traditional architectural nature up to the present date.

Regional Statistics, Vol. 8. No. 2. 2018: $92-108$; DOI: 10.15196/RS080208 
From a development policy and planning point-of-view, we were able to identify at least 4,779 farmsteads with residential and economic functions, but with no electricity, i.e. no connection to the power grid or an isolated power system, from the total sample. This is a definite point to target, for example, in the next development period of the EU. It is also important to highlight the relevance of agricultural policy, as, for half of the farmsteads, the proportion of the agricultural area around them is more than $80 \%$, while in the case of $27 \%$ of the farmsteads, less than onefifth of the area of the farmstead is used for arable farming.

In light of the preliminary research results presented in our study, it is considered that they did not fully meet the objective of the questionnaire survey. However, the data collected in the field and the database built from these data could be used as the basis of further analysis focusing on similar topics. We think that a more thorough and detailed analysis of the data could enable the development of dedicated funding for the different types of the farmsteads.

\section{Possible further research}

The authors believe that the data included in the database built during the survey should be clarified and supplemented in the future. We consider the field research worthy of being organized as a model programme, and within the framework of this field research, the general data concerning the farmsteads could be verified in the field. With the processing of the orthophotographs by the geographic information system provided by the Government Office of the Capital City Budapest, the maps showing the geographic location of the farmsteads can be more accurate. In case of the availability of a complete database, we think that, based on the general features of the farmsteads, the current farmstead typing can be renewed.

For this work, further useful data could be delivered by the HCSO Inspire database, which maps the resident population and dwelling stock of Hungary on a $1 \times 1$ $\mathrm{km}$ square grid. By comparing the data sets listed above and the state land cover and land use map files, the environmental changes of the scattered farmsteads can also be described.

In addition, the results of the 2016 survey could provide a basis for a GIS system that would include the location of surveyed farmsteads (based on GPS coordinates), public utilities, basic data of people living on the farm, and information on accessibility of farms (e.g. photographs showing the quality of farm roads). In the region of Gyula (a settlement in Békés county), there has been a similar system since 2013 (with an underlying database of about 700 farms), which greatly facilitates the work of local ambulances, firefighters, police, family support workers, farmstead caretakers, and social workers.

Finally, we believe it would be worthwhile to, once more, include farmstead surveys at regional and county levels into the grant announcements of the Farmstead

Regional Statistics, Vol. 8. No. 2. 2018: 92-108; DOI: 10.15196/RS080208 
Development Programme for upcoming years, as a grant objective would be useful. With the latter step, the changes of the farmstead areas could be checked and monitored.

\section{REFERENCES}

BECSEI, J. (2016): A tanya revitalizációjának mai lehetőségei In: SIKOS, T. T.-TINER, T. (ed.): Tájak, régiók, települések térben és idóben pp. 19-30., Dialóg Campus Kiadó, Budapest.

BELuszKY, P. (1983): A tanyaátalakulás jellemző folyamatai az elmúlt évtizedekben In: DÖVÉNYI, Z.-TÓTH, J. (ed.): Társadalmi-gazdasági változások és településstruktúránk. fejlódése pp. 81-96., Békéscsaba.

Czene, Zs.-JÁvor, K. (2006): A tanyák: XXI. századi végváraink, Helyzetkép a homokhátsági tanyákról $A$ Falu 21: 13-25.

CSATÁRI B.-KISS A. (ed.) (2004): Tanyai kaleidosqkóp, a 2002-2003. évi tanyakollégium munkájának eredményei MTA, RKK Alföldi Tudományos Intézete, Kecskemét.

Dobai, R. (et al.) (2018): A magyar tanyák és a Tanyafejlesztési Program 2011-2016 Földmúvelésügyi Minisztérium, Budapest.

DÖvÉNYI, Z. (2003): Településrendszer In: PERCZEL, GY. (ed.): Magyarorsðág társadalmigazdasági földrajza pp. 519-562., ELTE Eötvös Kiadó, Budapest.

Duró, A. (1990): A tanya és a zárt település kapcsolata - társadalomföldrajzi megközelítésben Tér és Társadalom 4 (2): 63-85. https://doi.org/10.17649/TET.4.2.174

FONT, E. (2006): Múlt vagy jövő? A Falu 21: 111-118.

GERÉB, L. (ed.) (2017): A székeely vidék fejlódési esélyei - kutatási jelentés Rega Egyesület, Székelyudvarhely.

HABLiCSEK, L. (2007): Népességünk következő évtizedei - különös tekintettel a területi különbségekre Demográfia 50 (4): 392-429.

KOZMA, Á. (2011): A tanya problematikája külföldiek termőföldtulajdon szerzésével kapcsolatban Jogelméleti Szemle http://jesz.ajk.elte.hu/kozma46.html (download: 2018.07.)

Kulcsár, L.-Kulcsár, J. L.-OBÁdovics, Cs (2011): Who lives in forgotten places? Age structure and socio-economic development in Hungary Regional Statistics 1 (1): 110-121.

NovÁK, G.-VARSÁNYI, T. (2011): The transport situation in the Great Plain Regional Statistics 1 (1): 135-148.

OBÁDOviCs, Cs. (2013): Regional level analysis of the population by real data and projections in Hungary Regional Statistics 3 (1): 57-78.

ROMVÁRI, R. (2017): Változások a tanyák szerepében A Falu 32 (2): 67-76.

SzABÓ, Sz. (2010): A CLC2000 és CLC50 adatbázisok összehasonlítása tájmetriai módszerekkel Tájökológiai Lapok 8 (1): 13-23.

SZÉKELY, A.-Kotosz, B. (2018): Kognitív térkép a dél-alföldi tanyák jövôképérôl Terïleti Statisztike 58 (3): 225-249. https://doi.org 10.15196/TS580301

SZILÁGYI, F. (2017): Partium településföldrajza és agráriuma Partium Kiadó, Nagyvárad.

Regional Statistics, Vol. 8. No. 2. 2018: $92-108$; DOI: 10.15196/RS080208 
Act number CXXII of 2013 on agricultural and forestry land trade

Farmstead Development Programme of the Kiskunmajsa area (2012).

HCSO (2017a): Magyarország 2016 kiadvány -

www.ksh.hu/docs/hun/xftp/idoszaki/mo/mo2016.pdf (download: 2018.06.28.)

HCSO (2017b): Az infokommunikációs technológiák és szolgáltatások helyzete Magyarországon, 2016

http://www.ksh.hu/apps/shop.kiadvany?p_kiadvany_id=993035\&p_temakor_k od=KSH\&p_lang=HU (download: 2018.09.11.)

HCSO (2018): Módszertani dokumentáció

http://www.ksh.hu/apps/meta.objektum?p_lang=HU\&p_menu_id=220\&p_ot _id=200\&p_obj_id=2325\&p_session_id=46890360 (download: 2018.06 .30 .)

HCSO (2019): Metainformation - Definition of Inhabited area in outskirts http://www.ksh.hu/apps/meta.objektum?p_lang=EN\&p_menu_id=210\&p_ot _id=200\&p_obj_id=2325\&p_session_id=49471409 (download: 2019.03.18.)

Hungarian Rural Development Programme 2014-2020.

Ministry of Agriculture (2018): Természetvédelmi adatok, Budapest.

National Development and Territorial Development Concept, Annex to Parliamentary Decree No. 1/2014. (I. 3.) OGY

National Spatial Development Concept (2005)

Regional Statistics, Vol. 8. No. 2. 2018: 92-108; DOI: 10.15196/RS080208 